\title{
Multiple Exponence on Archi Pronouns
}

\author{
Andrei Antonenko, Stony Brook University \\ Alice C. Harris, University of Massachusetts Amherst
}

In multiple exponence (ME) the same morpheme occurs multiple times within a single word. ME has been previously described in a number of languages of the Nakh-Dagestanian language family (Bokarev 1949, Harris 2009, Magometov 1961), as well as in other languages such as Limbu, Dumi, Athpare, and Chintang (Kiranti languages, a subgroup of Tibeto-Burman; Bickel et al. 2007, Ebert 1997, van Driem 1987, 1993, 1997, and elsewhere), Hualapai (Yuman) (Watahomigie et al. 1982), and Skou (Papua New Guinea) (Donohue 1999, 2003).

The examples in (1) demonstrate multiple occurrence of the gender (class) agreement marker (CM) on certain verbs and adjectives in Nakh-Dagestanian languages.
(1)a. $\underline{b}-a s ̌ a k ' u-\underline{b}$
(Chamalal)
b. $\underline{\mathrm{d}}-\mathrm{ex}-\underline{\mathrm{d}}-\mathrm{o}-\underline{\mathrm{d}}-\mathrm{ano}$
(Batsbi)
'short.SG.CLASS III'
CM-destroy-CM-PRES-CM-EVID
ע-eč'at'v-i
'black.SG.CLASS II'
(Bokarev 1949)
d-ek'- $\underline{\mathrm{d}}-\mathrm{iy}-\mathrm{e}^{\mathrm{n}}$
CM-fall-CM-TR-AOR
(Harris 2009)

In this paper we concentrate on the occurrence of ME in another Nakh-Dagestanian language, Archi. Archi is a language spoken in the Republic of Daghestan in the southern part of the Russian Federation. It belongs to the Lezgian group of the Nakh-Daghestanian family. Archi is spoken only in the village of Archib and currently has about 1,200 native speakers. The overwhelming majority of the speakers are bilingual in Archi and Russian. Like most of the Daghestanian languages, Archi is an SOV language (Testelets 1998), while most other word-orders are possible. It follows an ergative-absolutive pattern of case-assignment, in which the subjects of intransitive verbs and the objects of transitive verbs are marked with the absolutive case, while the subjects of transitive verbs are marked with the ergative case.

The agreement system in Archi and other Nakh-Dagestanian languages includes extensive use of gender class markers on verbs and adjectives. According to Kibrik (1977), the nouns in Archi are divided into eight classes; the corresponding agreement class markers appearing on the verbs for the first four, productive classes are given in (2). (2)

\begin{tabular}{|l|c|c|l|l|}
\hline Class & Singular & Plural & Example & Gloss \\
\hline I & $\mathrm{w}$ & $\mathrm{b}$ & bošor $\underline{\mathrm{w}}-\mathrm{i}$ & 'man is' \\
\hline II & $\mathrm{d} / \mathrm{r}$ & $\mathrm{b}$ & tonnol $\underline{\mathrm{d}}-\mathrm{i}$ & 'woman is' \\
\hline III & $\mathrm{b}$ & $\varnothing$ & $\mathrm{x}^{\text {Ion }} \underline{\mathrm{b}}-\mathrm{i}$ & 'cow is' \\
\hline IV & $\varnothing / \mathrm{t}$ & $\varnothing$ & q'onq' $\underline{\varnothing}-\mathrm{i}$ & 'book is' \\
\hline
\end{tabular}

Corbett (1991), following Kibrik (1977), shows that in Archi the multiple agreement marker can also occur on pronouns, and up to four CMs can surface in a word at the same time, as in (3).

(3) a. $\underline{\text { d}}-a \mathrm{as}: a-(a)-\underline{r}-(\mathrm{u})-\mathrm{ej}-\underline{r}-\mathbf{u}-\mathrm{t}: \mathrm{u}-\underline{\mathrm{r}}$ CM-of.myself-SUF-CM-SUF-SUF-CM-SUF-SUF-CM
'my own [female]'.

b. [ $\underline{\mathrm{d}}-\mathrm{as}: \mathrm{a}]-[(\mathrm{a})-\underline{r}-(\mathrm{u})]-[\mathrm{ej}-\underline{r}-\mathrm{u}]-[\mathrm{t}: \mathrm{u}-\underline{r}]$

Archi is the only language we are aware of where ME occurs in pronouns. In this paper we investigate the morphological structure of pronominal forms with $\mathrm{ME}$ in Archi, and demonstrate that the approach developed by Harris (2009) can account for their occurrence. 
Harris (2009) adopts the framework of word-and-paradigm morphology (Robins 1959, Matthews 1972, 1974, Aronoff 1994, Blevins 2006, Ackerman and Malouf 2006, Booij 2002, 2005) and argues that in Batsbi class markers occur as parts of "schemas." Schemas in Batsbi are of the type (CM)-MORPH, where MORPH can be either a lexical item or an affix, as demonstrated in (4). Crucially, if part of a schema occurs, the entire schema must occur. The schemas are given in the first column of the table, and columns 2 and 3 illustrate how the corresponding schema can be applied to both lexical items and affixes.

(4)

\begin{tabular}{|l|llll|}
\hline Schema & \multicolumn{2}{|l|}{ Lexical items } & \multicolumn{2}{l|}{ Affixes } \\
\hline CM-MORPH & d-ek'- 'fall' & -d-al & intransitive formant \\
\hline MORPH & ot'- & 'spread' & -it & causative suffix \\
\hline
\end{tabular}

Therefore, each morpheme is categorized as taking a class marker to its left or not at all.

Pronominal forms such as those in (3) consist of four independent morphemes, as in (3b), each taking a class marker. The first is a pronoun itself, the root, $(\mathrm{CM}+a s: a)$. The last occurrence of the CM accompanies the adjectivizer morpheme ( $t: u+C M)$ (Kibrik 1977), (5).

(5) a. baha 'price'

b. jat 'up'

baha-t:u-t 'pricey, dear'

c. qi 'during the day'

ja-t:u-t 'upper'

qi-t:u-t 'daily'

The third morpheme in (2b) is $e j+\mathrm{CM}+u$, which we, following Kibrik (1969) claim to be an emphatic marker. Its usage is exemplified in (6).

(6) a. Emphatic temporal adverbs

Tu-w-min sans-ej-b-u $\quad$ no'š $\quad$ b-ulneli.
he-I-GEN yesterday-ej-cM-u horse(III) cM-ran away.
'His horse ran away ALREADY YESTERDAY.'

b. Used with nouns for emphatic meaning/contrastive focus (Kibrik 1977:Vol. 2:326)

jasqi zon nokł-ej-w-u q'owdiqi, šut:a zon c'uraši xowt:i

today I(I) home-ej-cM-u stay tomorrow I Curib.Loc go

'Today I will stay at HOME, and tomorrow I will go to Curib'

c. Formation of certain forms of emphatic pronouns (Kibrik 1977: Vol 3, Appendix 4)
i. zari
I.ERG
'I'
i'. zar-ej-w-u
I.ERG-ej-CM-u
'I myself'
ii. wa-xur
YOU-COMPAR
'than you'
ii'. wa-xur-ej-w-u
YOu-COMPAR-ej-CM-u
'than you yourself'

The remaining sequence, $a+\mathrm{CM}+u$, has not been thoroughly discussed in the previous literature; we present data (some previously unnoticed) showing that $a+\mathrm{CM}+u$ can change the meaning in the following three ways: First, it provides "exhaustive-listing" focus on the pronoun (cf. Kuno 1973), (7). This Archi data can be compared with the Japanese data in (8). In Japanese examples, ga provides an exhaustive listing, which can be described by " $\mathrm{X}$ (and only X) ...", or "It is X that ...".
(7) a. zon nokłak $u-q^{\text {G } a}$
I.ABS house CM-entered
b. zon-a-w-u
noklak $u-q^{\complement} a$
'I entered the house'
I.ABS-SUF-CM-SUF house CM-entered
'Only I entered the house'

(8) John-ga gakusei desu.

(Kuno 1973)

John-GA student is

'(Of all the people under discussion) John (and only John) is a student'

Second, it changes a reflexive from long-distance to local, compare (9a) and (9b). 
(9) a. učiteli $i_{i}$ bo Mohamad-li $j_{j}$ inž $\check{i}_{i * j} \quad c<w>$ arši $w-i \quad$ boli teacher.ABS said Mohamad-ERG self $\langle\mathrm{CM}>$ praise CM-AUX COMP

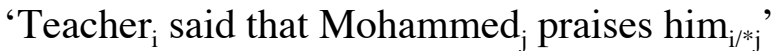

b. učiteli $i_{i}$ bo Mohamad-li $i_{j}$ inž-a- $w_{* i j j} \quad c<w>$ arši $w-i \quad b o l i$ teacher.ABS said Mohamad-ERG self-SUF-CM $<$ CM>praise CM-AUX COMP 'Teacher ${ }_{i}$ said that Mohammed $_{\mathrm{j}}$ praises himself $_{*_{\mathrm{i}} \mathrm{j}}$ '

Third, it distinguishes the 1st person inclusive pronoun from the exclusive.

Our preliminary proposal is that the "exhaustive-listing" meaning in the sense of Kuno (1973), as shown in (7) is the most basic, and that this meaning accounts for the use of this suffix in (5), and possibly in first person plural pronouns. We leave the precise description of this proposal for future research.

The corresponding schemas for all morphemes from (2) are given in (10).
(10) a. CM-as:a CM-MORPH
b. t:u-CM MORPH-CM
c. $\mathrm{a}-\mathrm{CM}-\mathrm{u} \sim \mathrm{MORPH}-\mathrm{CM}-\mathrm{MORPH}$
d. ej-CM-u MORPH-CM-MORPH

One can see that in comparison to Batsbi, allowing only schemas of the type CM-MORPH, Archi exhibits all logically possible varieties of schemas, where the class marker can be a prefix (10a), a suffix (10b), or an infix $(10 \mathrm{c}, \mathrm{d})$ to a corresponding morpheme.

In the last part of the paper, we consider examples such as (11) from Archi. As can be seen from comparison of (11a-b) and (11c-d), the morphemes $a-\mathrm{CM}-u$ and $e j-\mathrm{CM}-u$ cannot attach to only one reflexive pronoun, but must be attached to both of them simultaneously. This presents a problem for a schema-based account like that in Harris (2009).
(11)a. Učiteli bo student-lirši žu-t'-u žuss-u-t'-u kummul šit:e boli. Teacher said student-LOC self-CM-SUF self-SUF-CM-SUF food bought COMP
'The teacher $(\mathrm{m})$ told the student $\mathrm{i}_{\mathrm{i}}$ to buy food for himself ${ }_{\mathrm{i}}$ '
b. Učiteli bo student-lirši žu-t'-ej-t'-u žuss-u-t'-ej-t'-u kummul šit:e boli. self-CM-SUF-CM-SUF self-SUF-CM-SUF-CM-SUF
'The teacher $(\mathrm{m})$ told the student $\mathrm{i}_{\mathrm{i}}$ to buy food for himself $\mathrm{f}_{\mathrm{i}}$ '

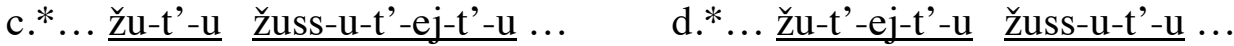

In order to resolve this problem, we propose that this sequence of reflexives forms a constituent, similar to the one shown in Russian examples in (12).
(12)a. Ivan kupil edu [ samomu sebe ]
I. bought food REFL $_{1}$.DAT REFL $_{2}$.DAT
'Ivan bought food for himself'
b. Ivan ljubit razgovarivat' s [ samim soboj]
I. likes talk.INF with REFL ${ }_{1}$.INST REFL 2 .INST
'Ivan likes to talk with himself'

In Russian, the sequence of reflexives in the examples in (12) forms a constituent, and the constituent has concordial case agreement (DAT in (12a) and INST in (12b)). We propose a parallel account of Archi $e j-\mathrm{CM}-u$ concord, based on the model of Russian. In Archi such obligatory co-occurrence of $e j-C M-u$ and $a-C M-u$ morphemes can be explained as a Focus Concord. Preliminary technical realization of this idea involves the existence of a focus projection, which dominates the constituent [pronoun pronoun]. We further propose that the focus head Foc0 undergoes concordial multiple agreement with both pronouns of the constituent, as shown in (13). We leave the details of this proposal for further research.

(13) [FocP Foc0 [pronoun pronoun]]

This paper provides additional arguments for a layered structure of words in languages with multiple exponence based on morphological schemas (Booij 2005, Harris 2009). We 
further propose that concord is responsible for the simultaneous occurrence of the morphemes, and it can be used to extend the analysis of Harris (2009) to account for Archi facts shown in (11). We also provide an analysis of Archi morphemes that are subcategorized for the use of Class Markers.

\section{References}

Ackerman, Farrell, and Robert Malouf. 2006. Patterns of relatedness in complex morphological systems and why they matter. Manuscript, University of California, San Diego. http://bulba.sdsu.edu/ malouf/papers/leipzig-handout.pdf. Accessed 20 March 2009.

Aronoff, Mark. 1994. Morphology by itself: Stems and inflectional classes. Cambridge: MIT Press.

Bickel, Balthasar, Goma Banjade, Martin Gaenszle, Elena Lieven, Netra Paudyal, Ichchha Purna Rai, Manoj Rai, Novel Kishor Rai, and Sabine Stoll. 2007. Free prefix ordering in Chintang. Language 83: 43-73.

Bokarev, A.A. 1949. Očerk grammatiki čamalinskogo jazyka. Moskva-Leningrad.

Booij, Geert. 2002. Constructional idioms, morphology, and the Dutch lexicon. Journal of Germanic Linguistics 14: 301-327.

Booij, Geert. 2005. Compounding and derivation: evidence for construction morphology. In Morphology and its demarcations, eds. Wolfgang U. Dressler, Franz Rainer, Dieter Kastovsky, and Oskar Pfeiffer, 109-132. Amsterdam/Philadelphia: John Benjamins.

Corbett, Greville G. 1991. Gender. Cambridge: Cambridge University Press.

Donohue, Mark. 1999. A most agreeable language. Paper presented at the conference of the Australian Linguistics Society, University of Western Australia, Perth, 30 September 1999. http://rspas.anu.edu.au/ donohue/Skou/SkouAGR.pdf. Accessed 15 March 2010.

Donohue, Mark. 2003. Agreement in the Skou language: a historical account. Oceanic Linguistics 42:478-498.

Ebert, Karen H. 1997. A grammar of Athpare. München: LINCOM Europa.

Harris, Alice C. 2009. Exuberant exponence in Batsbi. Natural Language and Linguistic Theory 27: 267-303.

Kibrik, A. E. 1977. Opyt strukturnogo opisanija arčinskogo jazyka. Volumes I, II, III. Izdatel'stvo Moskovskogo Universiteta.

Kuno, S. 1973. The structure of the Japanese language. MIT Press, Cambridge, Mass.

Magometov, Aleksandr A. 1961. O stroe glagola v Tabasaranskom jazyke. In Voprosy izučenija iberijsko-kavkazskix jazykov, ed. E.A. Bokarev, 227-239. Moskva: Akademija.

Matthews, Peter Hugoe. 1972. Inflectional morphology: a theoretical study based on aspects of Latin verb conjugation. Cambridge: Cambridge University Press.

Matthews, Peter Hugoe. 1974. Morphology: an introduction to the theory of word-structure. Cambridge: Cambridge University Press.

Robins, R. 1959. In defense of WP. Transactions of the Philological Society 116-44. Reprinted in Transactions of the Philological Society 99.2: 171-200.

van Driem, George. 1987. A grammar of Limbu. New York: Mouton de Gruyter.

van Driem, George. 1993. A grammar of Dumi. Berlin: Mouton de Gruyter.

van Driem, George. 1997. A new analysis of the Limbu verb. In Tibeto-Burman languages of the Himalayas (Papers in Southeast Asian Linguistics, No. 14), ed. David Bradley, 157173. Canberra: Pacific Linguistics.

Watahomigie, Lucille J., Jorogine Bender, Akira Y. Yamamoto, Elnora Mapatis, Josie Manakaja, and Malinda Powskey. 1982. Hualapai reference grammar. Los Angeles: American Indian Studies Center, University of California, Los Angeles. 